\title{
18 Fear of the dark
}

\author{
The potential impact of reduced \\ street lighting on crime and fear \\ of crime ${ }^{1}$
}

Pia Struyf

\subsection{Introduction}

Since the fifteenth century, street lighting has been installed in cities such as Paris and London as a means to combat crime (Boyce, 2014; Painter, 1999; Palmer, 2000). By 1850, most of the major cities worldwide had public lighting powered by gas, which later was replaced by exterior electric lighting systems (Boyce, 2014). At that time, providing public lighting had the specific aim of combating crime and maintaining public order, which gave rise to the "good lamp is the best police" metaphor (Bouman, 1991). Since the 1960s, the increasing crime rate led to local US governments and scientists investing in the crime prevention effect of public lighting (i.e., the installation of street lighting, or increases in the amount, or the intensity, of street lighting in dark public places), and its effect on fear of crime (Lee et al., 2016; Wright, Heilweil, Pelletier, \& Dickinson, 1974).

More recently, policymakers have shifted their interest toward the reduction of street lighting and its effects on the economy and the environment. In an era of climate change and economic cutbacks, local authorities around the world are considering reducing the amount of street lighting to decrease carbon emissions and save costs. Different interventions have been considered. For example, permanent or part-night switch-off (i.e., street lighting is only switched off during certain hours at night) and dimming lights, or replacing the existing lamps by more energy-efficient LEDs. In addition, new technologies have made smart, or intelligent applications, of street lighting possible. These promise to reduce energy waste and luminous pollution by providing public light only when necessary: illuminating a public space when a person approaches, and switching itself off when the person passes a certain spot, for example (Haans \& de Kort, 2012).

Despite the hypothetical benefits to the environment and the economy of reduced street lighting, evidence suggests that citizens consider the installation of street lighting as a "basic service" provided by the government, and express serious concerns about the possible impact of reduced street lighting on the occurrence of crime (Green, Perkins, Steinbach, \& Edwards, 2015). It is assumed that less public lighting will result in increased crime rates and unsafe public 


\section{Pia Struyf}

places. These concerns and assumptions generate fear amongst citizens, which affects both their mobility and use of public places (Steinbach et al., 2015).

Fear of crime is a broad concept which carries many sub-constructs, each with large variations in sensed risk, concern, anxiety, worry, and fear, resulting in the absence of a widely accepted definition. Consequently, measuring fear of crime constitutes a methodological challenge. According to Ferraro and LaGrange (1987), fear of crime is a perception that is solely based on subjective interpretations of objective risk, resulting in physical and psychological reactions such as a high heart rate and isolation. Different factors are highlighted as having an influence on the occurrence of fear of crime, such as biological (i.e., gender and age), psychological, and societal factors. Fear of crime has an uncomfortable effect on people and ought not be overlooked. However, scientific research on the impact of reduced street lighting on crime and fear of crime is still limited, and so local government decision-makers who consider reducing street lighting, are doing so through scientifically ill-informed processes.

This chapter critically reflects upon the impact of street lighting on crime and the fear of crime, with a particular emphasis on the effect of reduced street lighting. Together with an analysis of the relevant scientific databases, the extant literature, specifically the international literature on the impact of street lighting initiatives from 1960-2019, was investigated and reviewed. The synthesis of scholarly knowledge on the topic generated the following research questions:

1. Does street lighting affect crime and fear of crime?

2. What are the difficulties in measuring the effect of street lighting on crime and fear of crime?

3. Can we generalize about the impact of reduced street lighting on crime and fear of crime based on the scientific knowledge about street lighting installation, and the limited research on the reduction of street lighting?

4. What, if any, conflicting interests arise for local governments?

5. What lessons can be learned for research and practice?

This chapter critically evaluates the extant research on the impact of street lighting on crime and fear of crime and the methodological difficulties in measuring this. Further, the limited research on the impact of reduced street lighting on instances of crime and the fear of crime will be explored. The discussion will reflect on the expected impact of reduced street lighting on crime, the fear of crime, and the conflicting interests surrounding reduced street lighting policies. Finally, the chapter considers how far one can make generalizable conclusions based upon the available evidence, and the extent to which the findings provide a sound basis for future research and a secure platform for policymakers.

\subsection{Methodology}

The initial literature review was undertaken by scanning relevant scientific databases (i.e., Web of Science and Sage) using the following keywords: public 
lighting; street lighting; crime; antisocial behavior; wellbeing; fear of crime; improvements; reductions. Further, the snowball sampling method was used by screening the bibliographies of the found articles up until the point of saturation. No geographical criteria were adopted, although, only publications written in English were included.

On the basis that the intervention being researched was either a reduction in lighting (defined as permanent, partial, or dimmed lighting; or where lamps have been replaced with LEDs), or an increase in lighting (defined as the installation of new street lighting or an increase in the amount or intensity of street lighting in dark public places), the selection of articles was based on the following two criteria: (i) that the outcome was either the prevalence of crime or fear of crime (the incidence of traffic collisions was excluded), and; (ii) that the study was conducted between 1960 and 2019. Both qualitative and quantitative studies were included to reflect methodological nuance and advantages. The selected studies were all conducted in the United States and the United Kingdom, as studies that met the inclusion criteria were not found in other locations. $^{2}$

\subsection{The potential impact of (reduced) street lighting on crime and fear of crime}

\section{Street lighting as a crime prevention strategy}

Historically, darkness has always been associated with disorder and crime. Since the 1960s, several US local governments invested in the implementation of street lighting due to the increasing crime rate (Wright et al., 1974). Studies that examined the impact of increased street lighting on crime are numerous but come up with mixed results. Wright et al. (1974), evaluated a lighting project in Kansas City where incandescent lamps were replaced by mercury and sodium lights. They found that this initiative led to a decrease in the prevalence of certain types of crime, particularly robbery with violence and assault.

In contrast, Tien, O'Donnell, Barnett, and Mirchandani (1977), evaluated 15 street lighting projects in the US, and found no statistically significant effect of street lighting on crime. The authors selected street lighting projects based on five criteria: (i) the measured outcome must be the prevalence of crime; (ii) highway lighting projects were excluded as their focus is on vehicle safety rather than pedestrian safety; (iii) a population of at least 25,000; (iv) the projects were completed after 1970; and (v) the selected projects must provide pertinent evaluation-related information. In response to the Tien et al. review, Boyce (2014) pointed out that the studies included had several limitations, including inappropriate or inadequate measurements, and imprecise statistical analyses, which questioned their reliability (Boyce, 2014).

In the 1980s, several lighting projects were implemented by local governments in the United Kingdom. Atkins, Husain, and Storey (1991), researched the impact of street lighting in London on the prevalence of crime. They analyzed 
crime rates before and after relighting initiatives and compared these results to control areas where no such initiatives were taken. Critics argued that the assumption of Atkins et al. was restricted to the effect of street lighting on night-time crime (Pease, 1999). The study of Atkins et al. concluded that:

... no evidence could be found to support the hypothesis that improved street lighting reduces reported crime. Although some areas and some crime types did show reductions in night-time crime relative to the daytime control, the dominant overall pattern, from which the study draws its authority, was of no significant change.

(Atkins et al., 1991, p. viii)

Throughout the 1990s, Painter (1996, 1999; Painter \& Farrington, 1997) conducted substantial research on the impact of street lighting on crime. Her major comment on the previously conducted studies concerned the limited reliability of the police-recorded crime data that were used, due to the clustering of crime types and the low level of reported crimes (Boyce, 2014). A switch from police data to victim surveys offered a counterbalance to the difficulties with the first type of data source. However, victim surveys can only offer reliable results when a random sample is used to avoid selection bias. Using on-street pedestrian surveys in the treatment areas, before and after relighting initiatives were carried out after dark, Painter examined the impact of lighting on pedestrians' experiences of particular crimes (i.e., violence against the person, vehicle crime, and harassment) in a limited area in London. She concluded that street lighting does have a significant effect on crime. Further, she suggested that street lighting elicits a diffusion of benefits, implying that street lighting has a positive effect on non-relit streets nearby (Painter \& Farrington, 1999). For these areas, Painter found small decreases in crime, albeit that "most of the reductions reported relate more to threatening and disorderly incidents than to crime" (Painter, 1996, p. 197).

In a further study in Dudley, Painter and Farrington (1997) used two different data sources to examine the impact of street lighting on crime levels in a treatment and a control area, before and after street lighting improvements (the replacement of mercury lamps with high-pressure sodium lights). On the one hand, Painter and Farrington conducted interviews with randomly selected adult residents of the two investigated areas. These interviews showed that residents in the treatment area experienced less crime after the changes in street lighting compared to the control area. On the other hand, they carried out a self-reported delinquency survey from youngsters (age 12 to 17) living in both areas, which showed a larger decrease in admitted offenses in the relit area compared with the non-relit area.

In 2002 and 2008, Farrington and Welsh conducted two similar systematic reviews including eight American and five British studies, examining the impact of street lighting on crime (Farrington \& Welsh, 2002; Welsh \& Farrington, 2008 b). Five criteria were taken into account when selecting the included 
studies: (i) the main intervention in the studies was improved street lighting; (ii) the outcome measure was crime (mostly violent and property crimes); (iii) the studies must be of high methodological quality with measures before and after in treatment and control areas; (iv) the studies involved at least one treatment and one comparable control area; and (v) the areas examined in the studies must have at least 20 crimes in order for any change to have statistical significance.

The results of the eight American studies were mixed. Four studies reported results that confirmed the impact of street lighting, whereas the other four found no evidence of a crime prevention effect. In some cases, increases in certain types of crime were observed. This could be explained by increased reporting of crime to the police, as opposed to an increase in actual crime on the basis that offences are more visible to citizens when street lighting is increased. Overall, the meta-analysis conducted by Farrington and Welsh suggested a near-significant 7 percent decrease in crime in the relit areas of the included American studies. In contrast, the five British studies reported more uniform conclusions. The meta-analysis showed an overall 20 percent significant decrease in crime in the treatment areas compared with the control areas (Farrington \& Welsh, 2002; Welsh \& Farrington, 2008b).

Marchant $(2004,2005)$ argued that the statistical claims and methods used by Farrington and Welsh were unfounded, and further that there is a conflict between the evidence of the different studies and the interpretation of Farrington and Welsh. Two principal statistical errors were raised. The first, observed by Marchant was the 'unit of observation' error, by which he claims that related crimes (e.g., through repeat offending) were treated as statistically independent events. This resulted in a large variability in what the true underlying level of crime was. The second was the 'regression towards the mean' error, caused by comparing areas with different crime levels from the start. The treatment areas had higher crime rates than the control areas, resulting in a spurious increase in crime being recorded when comparing the two. Marchant stated that, based on this review, it was not possible to conclude that street lighting decreased or increased the prevalence of crime. Farrington and Welsh (2006) responded that regression to the mean only caused a 4 percent decrease in crime, which is a much smaller number than the overall decrease in crime attributed to street lighting.

More recently, Chalfin, Hansen, Lerner, and Parker (2019) conducted the first randomized controlled trial to examine the crime reducing effects of street lighting in New York City. To avoid selection bias, they randomly assigned the provision of street lighting to the city's public housing developments. Their focus was on index crimes (i.e., serious violent crimes) committed in 2016, based on the official police data of the NYPD from March 2011 to August 2016. The authors concluded that the provision of street lighting led to a 36 percent reduction in night-time index crimes, and a 4 percent reduction in overall index crimes, concluding that violent crimes can be especially sensitive to situational factors. It is notable that the lighting interventions made during this 


\section{Pia Struyf}

research, provided more light than other public lighting facilities, and further that the temporary nature of the interventions could have had an influence on the results. In a similar vein, the study does not consider the possible displacement of crime as a consequence of the installations.

To summarize, whilst the international literature overall is inconclusive on the crime prevention effect of street lighting (Boyce, 2014; Pain, MacFarlane, Turner, \& Gill, 2006; Steinbach et al., 2015), it is arguable that the more recent evidence supports the assumption that street lighting reduces crime, and thus, makes a difference. Nevertheless, it is very difficult to compare the results of the different studies in any meaningful way for five principal reasons. First, the studies discussed above lack an accepted definition of the concept of crime, indeed each study operationalizes 'crime' in different ways. Second, different studies examined different crime types and used different clusters of crimes. Third, different data sources were used, from police-recorded crime data to victim surveys and self-report surveys. Fourth, the different studies considered areas with diverse socio-economic characteristics and different crime rates. Fifth, all studies examined different types of 'improvements' to street lighting; inter alia relighting and changes in intensity.

\section{Street lighting as a fear of crime prevention strategy}

Although there is a worldwide decrease in crime, the fear of crime seems to remain at relatively stable levels (Eysink \& Foekens, 2018). As there is no causality between fear of crime and actual experienced victimization, fear of crime is a phenomenon created mostly by stories from other people's experiences, and general stories about crime and victimization, all of which could explain the overestimation of the least frequent crimes, and an underestimation of the most frequent crimes by citizens (Innes, 2017; Slovic, 2000). Consequently, this paradoxical relationship between crime, fear of crime, and the widespread impact of fear of crime on individuals, highlights the significance of studying the effect of street lighting on fear of crime.

Tien et al. (1977) were amongst the first to investigate the impact of street lighting on fear of crime in the US, by conducting an attitude survey in 15 US areas. Their results were straightforward, with 66 to 82 percent of the questioned residents and police officers reporting feeling "somewhat or much safer" after the installation of street lighting. Later, Atkins et al. (1991) researched the attitudes and behavior of residents in Earlsfield, London. They used self-reporting questionnaires before, and after, the relighting initiative in both treatment and control areas. The authors concluded that:

$\ldots$ in the relit or 'treated' areas, there was no general increase in feelings of safety about being out in the area after dark. There was however an observable improvement in women's perceptions of security, following re-lighting: this was statistically significant.

(Atkins et al. 1991, p. 14) 
No significant effects were noticed in the travel behavior of the respondents in the treatment area after the relighting was implemented. However, the implementation of street lighting was a popular measure with the respondents who were very much in favor. The most important limitations to this research was the comparatively short period in which the assessment was done and the small sample size (Atkins et al., 1991).

Later research echoed some of these findings. Painter (1996), for example, reported that street lighting led to decreased fear of crime, even when 'actual' changes were not consciously registered by residents. She argued that street lighting encourages more intensive use of public places after dark, which results in more natural social control of these areas (Painter, 1996). Similarly, Calvillo Cortés and Falcón Morales (2016) published research that examined the relationship between emotions and outdoor urban lighting. They compared three universities in three different countries (Mexico, Spain and France), where they used situation-response questionnaires to measure emotions to different lighting images. According to this study, the amount of visual information perceived in a place has an influence on people's emotions. When visual information was barely available, and the intensity of lighting was scarce, more respondents reported feelings of fear (Calvillo Cortés \& Falcón Morales, 2016).

Visibility in this context, namely the ability to see what is going on in the immediate surroundings, together with "eyes on the street" or natural surveillance, are significant factors when considering fear of crime. Different characteristics of the environment and public lighting have an impact on the feelings of safety in public places. For citizens, high levels of prospect (i.e., open view), low levels of concealment (i.e., few hiding opportunities for potential offenders), and low levels of entrapment (i.e., possibility to escape) are crucial elements in the assessment of a situation, and the potential to feel safe in public places (Dastgheib, 2018; Fisher \& Nasar, 1992). Other aspects, such as facial recognition, glare, and the color of light sources, play an equally important role in the assessment of street lighting where citizens' fear of crime is concerned (Boyce, 2014).

In summary, the presence of street lighting does result in less feelings of unsafety among citizens and more mobility after dark. Nevertheless, measuring the fear of crime is challenging. Fear of crime is often measured by examining attitudinal and behavioral changes of citizens, which results in very complex analysis and statistical interpretation (Atkins et al., 1991). Surveys for example, can be influenced by the type of questions asked, and by the phrasing used. Hypothetical questions are generally used in surveys to examine behavioral and attitudinal changes and reactions, although this type of question makes it difficult to value the results, if the respondents were not actually in the described situation (Ditton, 2000; Ramsay \& Newton, 1991). Therefore, it is important to keep the potential bias of responses in mind. 


\section{Pia Struyf}

\section{The effect of reduced street lighting on crime}

Whilst research on the impact of street lighting on crime and the fear of crime has been largely inconclusive and scarce respectively, academic research on the effect of reductions in street lighting on both crime and fear of crime also remains limited, with only a handful of recent studies touching the surface of this area. Perkins et al. (2015) for example, investigated the impact on crime of four street lighting adaptation strategies, by analyzing geolocated police data of eight areas in England and Wales (Perkins et al., 2015). For the same study, they conducted a rapid appraisal on the health and well-being concerns of the public after the implementation of four reduction strategies, namely, permanent switch-off, part-night switch off, dimming, and replacing traditional lamps by more energy-efficient LEDs (Steinbach et al., 2015). The study suggested that reduced street lighting had no significant increase on crime rates, although the opposite is generally assumed amongst citizens. Based on street lighting data and police data, permanent and part-night switch-off initiatives were not associated with an increase in crime, although dimming the street lights and replacing the lamps by LEDs were associated with a small reduction in crime, but their estimates were imprecise.

More recently, Davies and Farrington (2018) conducted a controlled before and after study of the effects on crime when switching off street lighting in Maldon, Essex (UK). The authors compared the treatment area with a demographically similar control area (Braintree, Essex), both served by the same police department (Essex Police). For both areas, only the urban wards with relatively high crime rates were taken into account. After comparing police recorded crime rates of the treatment (i.e., part-night lighting system since 2007) and control areas, three years before and after the introduction of the part-night lighting system, the authors concluded that switching off street lighting had the effect of a relative increase on burglary and vehicle crime. However, at the same time, criminal damage did not change, whilst violence showed a relative decrease in the treatment area, and might be explained by a decrease in people using public places after dark. As crime does not inevitably result in more (reported) crime, part-night lighting systems might be an interesting scenario for local governments who wish to reduce their public lighting, the authors conclude.

Overall, there seems to be evidence to suggest that reducing or switching off street lighting does not necessarily result in increases in crime, in the way that is mostly presumed. However, the available research is inconclusive and limited, with both studies showing certain limitations in terms of generalizability. First, the results of both studies are specific to the context of England and Wales, and therefore, cannot be generalized to other countries where lighting regimes and local government responsibilities differ. Second, in Perkins et al. (2015), only a small number of areas that implemented a permanent switch-off were included, so results concerning the lighting reduction strategy were imprecise. Similarly, in Davies and Farrington (2018), the size of the treatment area was relatively 
small compared with the control area, meaning any conclusions drawn are open to doubt. Finally, both analyses were based on police data, which are always partial since they are dependent on the willingness of citizens to report offences to the police, and the inclination of the police to register them (Skogan, 1975).

\section{The effect of reduced street lighting on fear of crime}

As noted above, studies concerned primarily with the effect of reduced street lighting on fear of crime are still limited. It is important to note that fear as a result of reduced street lighting does not exclusively mean fear of crime. Citizens are also fearful of tripping, physical injuries, and traffic accidents (Pain, 2000). Perkins at al.'s (2015) study focused on road safety, fear of crime, mobility, and the ability to see the night sky. They found that citizens expressed very strong and polarized views on public fora with an emphasis on the potential negative effects of reduced street lighting on their health and well-being, and a deep concern for their safety when walking at night. However, during the group interviews conducted by Perkins et al., they noticed that the opinions expressed were more modest. They recorded a greater emphasis on the possible positive effects of street lighting reductions, such as the reduction of carbon emissions and being able to see the stars at night. During their individual indepth interviews, a low degree of awareness about the reductions in street lighting amongst interviewees was noteworthy; several mentioned that they had not noticed any changes in street lighting. Yet in these interviews, respondents also expressed their concerns about personal safety and mobility. According to several respondents, mostly women, fear of the dark affected their mobility, as they were less likely to go out in the dark by foot, and were more likely to use the car or take a taxi. This fear of the dark is also strongly linked to unfamiliarity with places and situations. The household surveys carried out by Perkins et al., did not report any significant association between fear of crime levels and reduced street lighting; although it is possible that fear of the dark affected the well-being of citizens in other ways (Green et al., 2015).

Based on only one study, it is not possible to draw any generalizable conclusions on the impact of reduced street lighting on fear of crime, although the study of Perkins et al. suggests that people do change their behavior, and do feel less safe when street lighting is reduced in their area. As fear of crime affects the psychological and social abilities of people, more nuanced research that avoids some of the methodological pitfalls alluded to above is likely to give more fruitful outcomes.

\subsection{Discussion}

Notwithstanding the scarcity of empirical research on the subject, this chapter has critically examined the available international literature on increased and reduced street lighting with regard to crime and the fear of crime. It has been attentive to the hypotheses that might be generated based on their findings. In 
the literature, reduced street lighting is reflected as having the reverse effect of increased or installing street lighting. This reasoning is questionable. Most of these studies underplay the complexity of the social context, and are consequently less attentive to the diverse elements that might have unexpected and confounding effects on both the prevalence of crime and fear of crime. This makes any findings partial, and creates difficulties for both analytical and prescriptive conclusions about the impact of reduced street lighting on crime, and on the fear of crime.

Based on the analysis of the literature, two hypotheses can be put forward that explain the assumed crime prevention effect of street lighting. The first hypothesis asserts that street lighting provides visibility, which could deter potential offenders by increasing the possibility of crimes being detected and offenders identified (Atkins et al., 1991; Tien et al., 1977; Welsh \& Farrington, 2008a; Wright et al., 1974). According to situational crime prevention theories and the first generation of Crime Prevention Through Environmental Design (CPTED), it is possible to prevent crime by manipulating the urban context to influence the behavior and decision-making processes of offenders.

Based on this hypothesis, can we anticipate an increase in crime? This assumption, based largely on rational choice premises embedded in situational crime prevention, is highly questionable. First, as Wortley (2010) argues, situational crime prevention reduces its focus almost exclusively to target-hardening, thus neglecting the social context where interacting factors of crime, such as poverty, inequality, discrimination and poor parenting, are likely to play a role (Wortley, 2010). Second, attention should be paid to the possibility of crime displacement to nearby non-relit areas (Wright et al., 1974). This displacement of crime could be an unintended outcome of the installation or increase of street lighting and could result in increased crime rates in nearby areas. Further, increases in crime rates in a certain, potentially unlit area, do not necessarily indicate an overall increase in crime rates. Third, in-depth research is necessary on the decision-making processes of offenders, such as burglars (Ramsay \& Newton, 1991). In the study of Bennett and Wright (1984) for example, no mention was made about the lighting conditions affecting the interviewed burglars when choosing their target (Ramsay \& Newton, 1991). Based on these critiques, a rational choice approach does not offer a nuanced enough analytical toolkit to consider the impact of reduced street lighting on crime and fear of crime.

A second widely asserted hypothesis relates to the increased social cohesion created by street lighting. This hypothesis asserts that street lighting provides visibility, which leads to an increased use of public places during darkness. Therefore, more people are present in specific public places, leading to more natural surveillance, which results in less crime and citizens feeling safer. Further, the presence of street lighting, seen as a symbol of the positive attention of local governments, promotes certain neighborhoods and militates against the degradation of these areas. The logic at play is that social cohesion leads to community pride and informal social control of the own neighborhood 
(Boyce, 2014; Farrington \& Welsh, 2004). When considering the reduction of street lighting, it is generally assumed by citizens and other actors that fear of crime will be higher as a consequence of darker public places. In this respect, attention must be paid to confounding variables, such as the familiarity with the place and the reputation of a certain neighborhood. Therefore, no conclusive prediction can be made, based on this hypothesis, about the impact of reduced street lighting on crime and fear of crime.

\subsection{Conflicting interests and lessons learned}

Although reducing street lighting may cause a reduction in carbon emissions and bear down on financial costs, the perceptions of being (un)safe cannot be overlooked. On the one hand, local, national and international authorities are taking action against the environmental changes by decreasing carbon emissions, as well as more subjective factors such as light pollution, by reducing street lighting. On the other hand, there are simultaneous investments in crime prevention initiatives, seeking to protect citizens against different types of crimes. Crime prevention measures often have the paradoxical effect of reigniting the fear of crime, due to the increased awareness of risks (Innes, 2017), and reduced street lighting is seen as a measure that increases these senses, and are consequently difficult to overrule on grounds of the environmental protection or financial probity. I would suggest that there is no logical reason to suppose that environmental imperatives, and taking account of the fears of citizens, are mutually exclusive. However, authorities that decide to reduce street lighting must be aware of these conflicting values and must be scientifically informed during their decision-making process.

There seems to be little evidence to support switching off all street lighting permanently. Instead, consideration should be given to strategies that provide for "the right amount of light", meaning that lighting must be adequate to the specific situation calculated as a balance between energy savings and comfortable citizens. For example, good illumination is necessary in parks to facilitate natural surveillance and increase feelings of safety amongst passers-by (Iqbal \& Ceccato, 2016). In residential areas, on the other hand, street lighting can be switched off during certain hours of the night when citizens are unlikely to be regularly using public space. As stated by Davies and Farrington (2018), partnight switch off can be an effective and justifiable street lighting regime, but only after a thorough assessment of the context and needs of the neighborhood. To advise local governments in their street lighting regime, more scientific research must be carried out with attention to the particular social and physical environment.

Future studies then, on the effect of (reduced) street lighting on crime and, especially the fear of crime, need to develop methodological approaches that allow for a clear operationalization of these concepts. This makes it possible to compare studies at a more comprehensive level to accommodate different types of crime and fear of crime. A triangulation of methods could also help to 
counteract the limitations of different methods and avoid the forms of bias noted in this chapter. For example, it could be helpful to combine several forms of data, such as police-recorded data, self-reported offending data, victim surveys, and pedestrian counts, in a mixed methods study that is able to draw more nuanced findings. To conclude, clear operationalization of the concepts, and triangulation of methods is necessary to ensure the validity, credibility, and generalization of findings.

\subsection{Conclusion}

This chapter examined the limited literature on the impact that (reduced) street lighting can have on crime and the fear of crime. The studies in the literature show mixed results, but they do indicate that street lighting can have a crime reducing effect and can reduce fear of crime. However, there is no concomitant link between reduced street lighting and an increase in the prevalence of crime. The literature concerning the impact of reduced street lighting on fear of crime is too scarce to make conclusions. However, reduced street lighting might raise the awareness among citizens of the possible risks and negative effects of reduced street lighting, but also stresses its positive consequences, such as environmental benefits. Nevertheless, citizens did report some degree of behavioral changes during the night-time, such as their mobility. These findings should provide more scientific knowledge to local governments in their decision-making processes concerning the reduction of street lighting to save costs and reduce carbon emissions, which should be balanced against the well-being of their citizens.

The findings of this chapter are subject to three limitations. First, a literature review was conducted to offer a summary of the scientific knowledge related to the effect of (reduced) street lighting on crime and fear of crime. No systematic review or meta-analysis was done, so the conclusions should be interpreted as preliminary. Additionally, we must be aware of the possible publication bias in social sciences and, thus, possible distortion of the findings discussed in this chapter (Franco, Malhotra, \& Simonovits, 2014). Second, only a limited series of street lighting adaptation regimes were reviewed, with restricted attention for other, "smart", alternatives, such as street lighting that illuminates when a person passes by. Third, it remains unclear what the influence was (or could be) of other crime prevention initiatives that existed alongside street lighting. It is a challenge to measure the impact of interventions that have the objective of preventing certain behavior or emotions; thus, the impact of increased and reduced street lighting needs to be evaluated not only within the social contexts in which they are deployed, but also in their potential interaction with other prevalent crime prevention initiatives.

\section{Notes}

1 This chapter is based upon findings from a research project funded by Provincie West-Vlaanderen, Belgium. Alongside this literature review, a practical guide for local 
governments was written (Struyf, Enhus, Melgaço, \& Bauwens, 2019). The guide highlighted the most important findings on the impact that reduced street lighting has on crime and fear of crime, as well as providing practical information and advice to local governments wishing to implement reduced street lighting.

2 There is also research available on this topic not written in English (i.e., Ceccato, Vasquez, Langefors, Canabarro, \& Petersson, 2019, pp. 76-80).

\section{References}

Atkins, S., Husain, S., \& Storey, A. (1991). The Influence of Street Lighting on Crime and Fear of Crime. London: Home Office Crime Prevention Unit.

Bennett, T., \& Wright, R. (1984). Burglars on Burglary: Prevention and the Offender. Brookfield, USA: Avebury Publishing.

Bouman, M. J. (1991). The 'Good lamp is the best police' metaphor and ideologies of the nineteenth-century urban landscape. American Studies, 32, 63-78.

Boyce, P. R. (2014). Human Factors in Lighting. Boca Raton: CRC Press.

Calvillo Cortés, A. B., \& Falcón Morales, L. E. (2016). Emotions and the urban lighting environment: a cross-cultural comparison. SAGE Open, 6, 1-8.

Ceccato, V., Vasquez, L., Langefors, L., Canabarro, A., \& Petersson, R. (2019). Trygg stadsmiljö. Teori och praktik för brottsförebyggande \& trygghetsskapande àtgärder. Stockholm, Sweden: Institutionen för samhällsplanering och miljö, Kungliga Tekniska Högskolan.

Chalfin, A., Hansen, B., Lerner, J., \& Parker, L. (2019). Reducing crime through environmental design: evidence from a randomized experiment of street lighting in New York City. NBER Working Paper Series, 25798.

Dastgheib, S. (2018). Light and Perception of Safety In-between Buildings. The Role of Lighting in Perception of Safety from a Female Perspective in In-between Spaces of Residential Areas. Stockholm: KTH School of Architecture and Built Environment.

Davies, M. W., \& Farrington, D. P. (2018). An examination of the effects on crime of switching off street lighting. Criminology \& Criminal Justice, 1-19.

Ditton, J. (2000). Crime and the city. British Journal of Criminology-an International Review of Crime and Society, 40, 692-709.

Eysink, M., \& Foekens, P. (2018). The fear drop. In M. Lee \& G. Mythen (Eds.), The International Handbook of Fear of Crime (pp. 446-466). New York: Routledge.

Farrington, D. P., \& Welsh, B. C. (2002). Effect of Improved Street Lighting on Crime: A Systematic Review. London: Home Office.

Farrington, D. P., \& Welsh, B. C. (2004). Measuring the effects of improved street lighting on crime. A reply to Dr. Marchant. British Journal of Criminology, 44, 448-467.

Farrington, D. P., \& Welsh, B. C. (2006). How important is 'Regression to the mean' in area-based crime prevention research? Crime Prevention \& Community Safety, 8, 50-60.

Ferraro, K. F., \& LaGrange, R. (1987). The measurement of fear of crime. Sociological Inquiry, 57, 70-101.

Fisher, B. S., \& Nasar, J. L. (1992). Fear of crime in relation to three exterior site features: prospect, refuge, and escape. Environment and Behavior, 24, 35-65.

Franco, A., Malhotra, N., \& Simonovits, G. (2014). Publication bias in the social sciences: unlocking the file drawer. Science, 345, 1502-1505.

Green, J., Perkins, C., Steinbach, R., \& Edwards, P. (2015). Reduced street lighting at night and health: a rapid appraisal of public views in England and Wales. Health o Place, 34, 171-180.

Haans, A., \& de Kort, Y. A. W. (2012). Light distribution in dynamic street lighting: two experimental studies on its effects on perceived safety, prospect, concealment, and escape. Journal of Environmental Psychology, 32, 342-352. 
Innes, M. (2017). From fear to understanding. 'Making' and managing public reactions to crime, disorder and policing. In N. Tilley \& A. Sidebottom (Eds.), Handbook of Crime Prevention and Community Safety (pp. 470-487). London: Routledge.

Iqbal, A., \& Ceccato, V. (2016). Is CPTED useful to guide the inventory of safety in parks? A study case in Stockholm, Sweden. International Criminal Justice Review, 26, 150-168.

Lee, J., Park, S., Jung, S., Lee, J. S., Park, S., \& Jung, S. (2016). Effect of Crime Prevention through Environmental Design (CPTED) measures on active living and fear of crime. Sustainability, 8,872 .

Marchant, P. (2004). A demonstration that the claim that brighter lighting reduces crime is unfounded. British Journal of Criminology, 44, 441-447.

Marchant, P. (2005). Shining a light on evidence-based policy: street lighting and crime. Criminal Justice Matters, 62, 18-45.

Pain, R. (2000). Place, social relations and the fear of crime: a review. Progress in Human Geography, 24, 365-387.

Pain, R., MacFarlane, R., Turner, K., \& Gill, S. (2006). 'When, where, if, and but': qualifying GIS and the effect of streetlighting on crime and fear. Environment and Planning, 38, 2055-2074.

Painter, K. A. (1996). The influence of street lighting improvements on crime, fear and pedestrian street use, after dark. Landscape and Urban Planning, 35, 193-201.

Painter, K. A. (1999). The social history of street lighting (part 1). Lighting Journal, 64, 14-24.

Painter, K. A., \& Farrington, D. P. (1997). The crime reducing effect of improved street lighting: the Dudley project. In R. V. Clarke (Ed.), Situational Crime Prevention: Successful Case Studies. www.ncjrs.gov/App/Publications/abstract.aspx?ID=259348.

Painter, K. A., \& Farrington, D. P. (1999). Street lighting and crime: diffusion of benefits in the Stoke-on-Trent project. Crime Prevention Studies, 10, 77-122.

Palmer, B. D. (2000). Cultures of Darkness: Night Travels in the History of Transgression. New York: Monthly Review.

Pease, K. (1999). A review of street lighting evaluations: crime reduction effects. In K. A. Painter \& N. Tilley (Eds.) Surveillance of Public Space: CCTV, Street Lighting and Crime Prevention (pp. 47-76). Cincinnati, OH: Criminal Justice Press.

Perkins, C., Steinbach, R., Tompson, L., Green, J., Johnson, S., Grundy, C., ... Edwards, P. (2015). What is the Effect of Reduced Street Lighting on Crime and Road Traffic Injuries at Night? A Mixed-Methods Study. Southampton, UK: NIHR Journals Library.

Ramsay, M., \& Newton, R. (1991). The Effect of Better Street Lighting on Crime and Fear: A Review. London: Home Office Crime Prevention Unit.

Skogan, W. G. (1975). Measurement problems in official and survey crime rates. Journal of Criminal Justice, 3, 17-32.

Slovic, P. (2000). The Perception of Risk. New York: Earthscan.

Steinbach, R., Perkins, C., Tompson, L., Johnson, S., Armstrong, B., Green, J., ... Edwards, P. (2015). The effect of reduced street lighting on road casualties and crime in England and Wales: controlled interrupted time series analysis. Journal of Epidemiology and Community Health, 69(11), 1118-1124.

Struyf, P., Enhus, E., Melgaço, L., \& Bauwens, T. (2019). De impact van ingrepen in de openbare verlichting op criminaliteit, onveiligheidsgevoelens en verkeers(on)veiligheid. Praktijkgids voor lokale bestuurders en -administratie. Brussels: Vrije Universiteit Brussel.

Tien, J. M., O’Donnell, V. F., Barnett, A. I., \& Mirchandani, P. B. (1977). Street Lighting Projects. Washington: National Institute of Justice. 
Welsh, B. C., \& Farrington, D. P. (2008a). Effects of improved street lighting on crime. Campbell Systematic Review, 4(1), 1-51.

Welsh, B. C., \& Farrington, D. P. (2008b). Effects of improved street lighting on crime: a systematic review. Campbell Systematic Reviews, 4. http://campbellcollaboration. org/lib/project $/ 45 /$.

Wortley, R. (2010). Critiques of Situational Crime Prevention. http://discovery.ucl.ac. uk/1301877/1/Wortley_2010_SCP_criticisms.pdf.

Wright, R., Heilweil, M., Pelletier, P., \& Dickinson, K. (1974). The Impact of Street Lighting on Crime. Ann Arbor, MI: University of Michigan. 